\title{
B2GPI exerts an anti-obesity effect in female mice by inhibiting lipogenesis and promoting lipolysis
}

\author{
Shangwen Dong ${ }^{1,2}$, Miao Qi ${ }^{1}$, Ying Wang ${ }^{1,3}$, Liming Chen ${ }^{3}$, James Crofton Weaver ${ }^{4}$, \\ Steven Antony Krilis ${ }^{1, *}$ and Bill Giannakopoulos ${ }^{1,5, *}$ \\ ${ }^{1}$ Department of Infectious Diseases, Immunology and Sexual Health and Department of Medicine, St George Hospital, \\ University of New South Wales, New South Wales, Sydney, Australia \\ ${ }^{2}$ Department of Cardiothoracic Surgery, Tianjin Medical University General Hospital, Tianjin Medical University, Tianjin, China \\ ${ }^{3}$ Laboratory of Hormones and Development (Ministry of Health), Metabolic Hospital and Tianjin Institute of Endocrinology, \\ Tianjin Medical University, Tianjin, China \\ ${ }^{4}$ Department of Cardiology, St George Hospital, New South Wales, Sydney, Australia \\ ${ }^{5}$ Department of Rheumatology, St George Hospital, New South Wales, Sydney, Australia \\ * These authors have contributed equally to this work \\ Correspondence to: Bill Giannakopoulos, email: bill.giannakopoulos@unsw.edu.au \\ Keywords: apolipoprotein $\mathrm{H}, \beta_{2}$-glycoprotein I, obesity, sexual dimorphism, lipogenesis \\ Received: May 18, $2017 \quad$ Accepted: July 12, $2017 \quad$ Published: October 04, 2017 \\ Copyright: Dong et al. This is an open-access article distributed under the terms of the Creative Commons Attribution License 3.0 \\ (CC BY 3.0), which permits unrestricted use, distribution, and reproduction in any medium, provided the original author and source \\ are credited.
}

\section{ABSTRACT}

In humans, males compared to females have increased visceral adipose tissue which contributes to their increased risk of early death. Mice display analogous sexual diamorphism whereby females are protected from weight gain when fed a high fat diet compared to males. A role has recently been reported for $\boldsymbol{\beta}_{2}$-glycoprotein $I$, an abundant plasma protein, in healthy leanness in humans. In this study we investigated the role of $\beta_{2}$-glycoprotein $I$ in fat metabolism in male and female mice fed a normal chow or high fat diet. We have made a number of novel insights into factors contributing to sexual diamorphism in obesity. Female wild type mice are protected from obesity when fed a high fat diet due to down regulation of lipogenesis in the visceral adipose tissues. This down regulation is due to $\beta_{2}$-glycoprotein $I$ as female mice deficient in this protein have increased levels of lipogenesis enzymes in their visceral adipose tissues with an accompanying increase in weight compared to female wild type controls. Understanding female specific regulators of obesity may lead to sex specific anti-obesity therapies to address this major health problem.

\section{INTRODUCTION}

Obesity is a major worldwide health problem. A pooled analysis including 19.2 million individuals from 200 countries between the years of 1975 to 2014 found an increase in the age standardised prevalence of obesity in men from $3.2 \%$ of the population in 1975 to $10.8 \%$ in 2014, and for women from $6.4 \%$ to $14.9 \%$. If such trends continue it is estimated that by 2025 global obesity prevalence will reach $18 \%$ in men and surpass $21 \%$ in women, whilst severe obesity will surpass $6 \%$ in men and $9 \%$ in women [1]. In a meta-analysis of over 200 prospective studies from multiple regions found a consistent association between obesity with higher all-cause mortality [2]. In conjunction with the increased availability and consumption of inexpensive, high energy foods, and a decrease in physical activity, leading to net energy storage rather than energy expenditure, other important factors predisposing an individual to an increased risk of developing obesity are multiple genetic susceptibility loci delineated in genome wide association studies, including a number that map near hypothalamic regulators of energy balance [3]. The strongest genomewide association signal lies in introns 1 and 2 of the gene Fat Mass and Obesity Associated variant (FTO), which has been found to repress mitochondrial thermogenesis in adipocyte precursor cells [4]. 
Starting at puberty, females compared to males have a tendency to accumulate fat in the subcutaneous tissue such as the hips and thighs, whilst there is marked difference in the waist to hip ratio, being consistently greater in males compared to females [5]. Central obesity which reflects visceral adiposity as measured by the waist to hip ratio and is an independent risk factor from overall adiposity (the latter measured by the body mass index), for type 2 diabetes mellitus [6,7], coronary heart disease [8] and mortality from all causes [9]. This sexual dimorphism in fat distribution may account to some extent why men compared to women, for an identical BMI in the obesity range, have a higher all cause mortality rate [2]. This sexual diamorphism has also been noted in the rodent C57BL/6J strain where female wild type (WT) mice compared to male WT mice were protected from obesity for up to 15 weeks when fed a high fat diet [10].

Beta 2-glycoprotein I ( $\beta 2 \mathrm{GPI}$ ) (also known as apolipoprotein $\mathrm{H}$ ) is an abundant plasma protein that is produced in the liver. It belongs to the complement control protein superfamily of molecules, and it has been shown to be strongly conserved in the evolutionary line, being present in all mammals, but also in birds, fish, and reptiles [11].

Over the past few years a complex association between $\beta 2$ GPI and obesity has been emerging in unbiased, non-hypothesis driven, exploratory, association seeking studies in the context of obesity. It has been noted in studies involving zebra fish, rats, mice [12], pigs [13] and beef cattle [14] that there is upregulation of either $\beta 2 \mathrm{GPI}$ gene transcription or $\beta 2 \mathrm{GPI}$ protein expression in the adipose tissue of obese animals compared to tissue from non-obese species controls. This relation has also been noted to hold in humans, where it was noted the plasma levels of $\beta 2$ GPI positively correlates with body fat [15]. $\beta 2$ GPI protein levels have also been noted to be increased in the liver and plasma of type 2 diabetic patients with metabolic syndrome [16]. In a recent genetic study the combination of a certain FTO polymorphism with a certain $\beta 2$ GPI polymorphism conferred a protective effect towards healthy thinness [17]. In another study the level of $\beta 2$ GPI in the adipose tissue in individuals with the proobesity FTO polymorphism was upregulated [4]. These studies raise the fascinating question of whether $\beta 2$ GPI has a causal role in modulating obesity. We sought to address this question using $\beta 2 \mathrm{GPI}$ deficient mice on a C57BL/6J background and comparing them to identically housed and fed gender and age matched wild type C57BL/6J mice.

\section{RESULTS}

\section{Wild type females fed a high fat diet are protected from obesity which is lost in the absence of $\beta 2$ GPI}

Female $\beta 2 \mathrm{GPI} /-$ mice gained significantly more weight than female WT mice when fed a high fat (HF) diet which was observed from week 1 and continued out to week $16(\mathrm{p}<0.05$, Figure 1A). For the first 12 weeks the WT female mice fed a HF diet were the same weight as the WT females that were fed on normal chow (NC). However at weeks 12-16 the WT females fed a HF diet started to gain more weight than the NC fed WT females (Figure 1A). This early anti-obesity phenomenon has previously been reported [10]. However, the body weight of the male $\beta 2$ GPI-/- mice were not significantly different from male WT mice from week 1 to 16 weeks of HF diet ( $p>$ 0.05 , Figure 1B). The male WT mice fed a HF diet gained significantly more weight from week 1 compared to the male WT mice fed NC diet, (Figure 1B) emphasising the

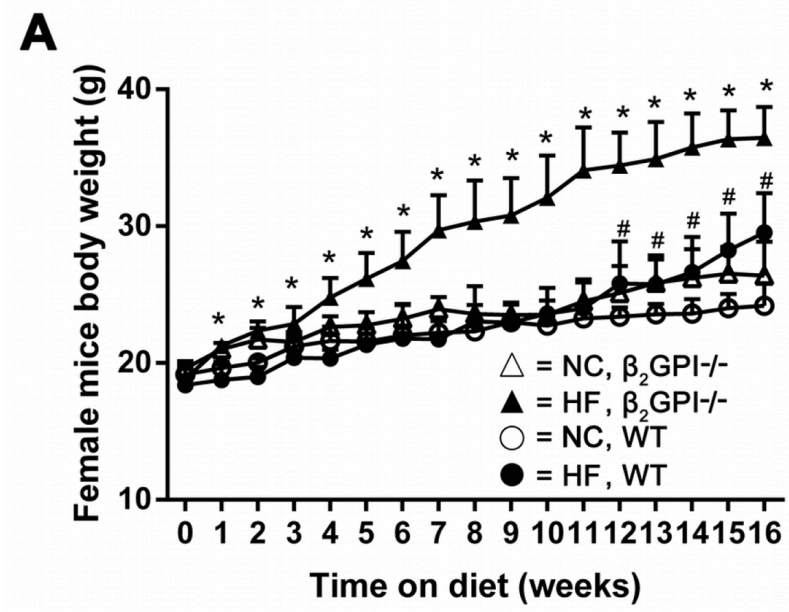

B

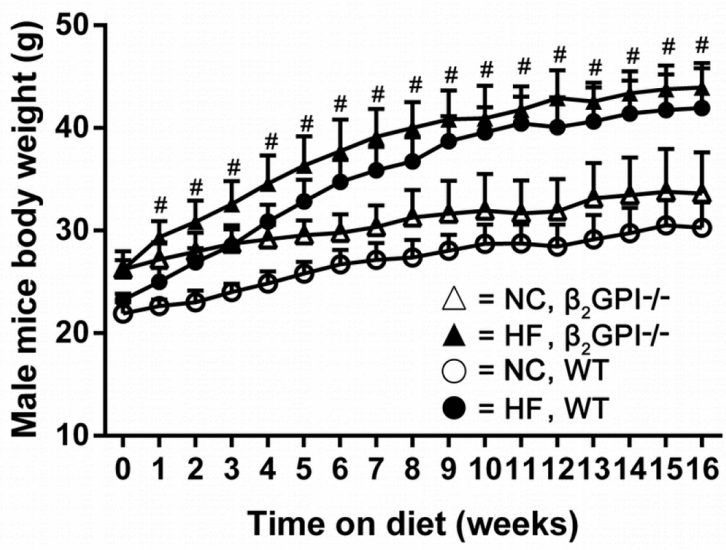

Figure 1: Body weight of $\beta 2$ GPI-/- compared to WT mice recorded on a weekly basis for 16 weeks. (A) Female; (B) male: $\mathrm{O}=\mathrm{NC} \operatorname{diet} \mathrm{WT} ; \bullet=\mathrm{HF}$ diet WT, $\Delta=\mathrm{NC} \operatorname{diet} \beta 2 \mathrm{GPI}-/-, \boldsymbol{\Delta}=\mathrm{HF}$ diet $\beta 2 \mathrm{GPI}-/-$. Data are expressed as mean $\pm \mathrm{SD}, \mathrm{n}=4-5 \mathrm{mice}$ per group. ${ }^{*} \mathrm{p}<0.05$, significantly greater weight in genotype comparisons; ${ }^{\#} \mathrm{p}<0.05$, significantly greater weight in diet comparisons. $\mathrm{NC}=\mathrm{normal}$ chow, $\mathrm{HF}=$ high fat. 
sexual diamorphism of this early anti-obesity phenomenon as previously reported.

\section{The absence of $\beta 2$ GPI promotes an increase in visceral fat in female mice fed either a normal chow or high fat diet}

We measured the weight of visceral adipose tissue (VAT). In female mice we quantitated the parametrial fat, while for the male mice we quantitated epididymal fat, the major visceral fat depots in female and male rodents respectively. Female $\beta 2 \mathrm{GPI} /-$ mice had significantly increased parametrial fat deposits compared to female WT mice fed either NC or a HF diet ( $<<0.05$, Figure $2 \mathrm{~A})$. There was no difference in the quantity of epididymal fat between male $\beta 2 \mathrm{GPI} /-$ and diet matched male WT mice $(p>0.05$, Figure $2 B)$.

\section{Female $\beta 2 \mathrm{GPI}$-/- mice fed a high fat diet demonstrate difference in adipocyte morphology, macrophage infiltration of VAT and increased plasma CRP}

The mean adipocyte area of parametrial/epididymal VAT is shown in Figure 3. Mice fed HF diet show enlargement of adipocytes, moreover, the adipocyte size of female $32 \mathrm{GPI} /-$ mice fed HF diet was significantly larger than female diet matched WT mice $(\mathrm{p}<0.05$, Figure 3A). Representative images of adipocytes from female and male cohorts are shown in Figure 3B and 3D respectively). There was no difference in the adipocyte size between male $\beta 2 \mathrm{GPI}-/$ - and male WT mice fed either $\mathrm{NC}$ or a HF diet $(\mathrm{p}>0.05$, Figure $3 \mathrm{C})$. There is increased macrophage infiltration in the VAT of female $\beta 2 \mathrm{GP}-/$ - mice fed a HF diet compared to female WT mice fed a HF diet (Figure 3E, 3F). There was no difference in macrophage infiltration in the VAT of male $\beta 2 \mathrm{GPI} /-$ mice fed a HF or NC diet compared to WT controls (Figure 3G, 3H).

Female $\beta 2 \mathrm{GPI} / \mathrm{-}$ fed a HF diet have higher plasma $\mathrm{C}$ reactive protein (CRP) levels $9.34 \pm 0.82 \mu \mathrm{g} / \mathrm{ml}$, mean \pm $\mathrm{SD}, \mathrm{n}=5$ compared to female WT mice fed a HF diet 7.18 \pm 0.70 , mean $\pm \mathrm{SD}, \mathrm{n}=5,(\mathrm{p}<0.05)$. This difference was not observed in female $\beta 2 \mathrm{GPI}-/$ - mice fed a NC diet, 5.12 $\pm 1.28 \mu \mathrm{g} / \mathrm{ml}$ compared to female WT mice fed a NC diet, $4.95 \pm 1.30 \mu \mathrm{g} / \mathrm{ml}$, mean $\pm \mathrm{SD}, \mathrm{n}=5, \mathrm{p}>0.05$.

\section{及2GPI deficiency regulates lipogenesis enzymes in female VAT}

ATP citrate lyase (Atpcl) catalyzes the formation of acetyl-CoA from citrate [18]. Phosphorylation of serine (Ser) 455 in Atpcl enhances the catalytic activity of the enzyme and the conversion of citrate to acetyl-CoA [19, 20]. Acetyl-CoA carboxylase (Acc) is responsible for the formation of malonyl-CoA from acetyl-CoA [21]. Phosphorylation of Acc at Ser79 will inhibit its activity [22]. Malonyl-CoA regulates lipid oxidation through the inhibition of the mitochondrial enzyme carnitine palmitoyltransferase-1 and promotes lipogenesis through the provision of a key substrate [23]. A decrease in the activity of Acc inhibits lipogenesis by lowering of cellular malonyl-CoA [22]. Fatty acid synthase (FAS) is a crucial enzyme for de novo lipogenesis by converting malonylCoA to fatty acids [18]. When female WT mice were fed a HF diet there was a highly significant down regulation of lipogenesis enzymes compared to female WT mice fed NC (Figure 4A, 4B). In contrast male WT fed a HF diet had a dramatic increase in lipogenesis enzyme expression in VAT compared to male WT fed a NC diet (Figure 4B). There was no difference in phosphorylation of Acc (Ser 79) and Atplc (Ser455) for the male mice (data not shown). In addition there was a significant decrease in
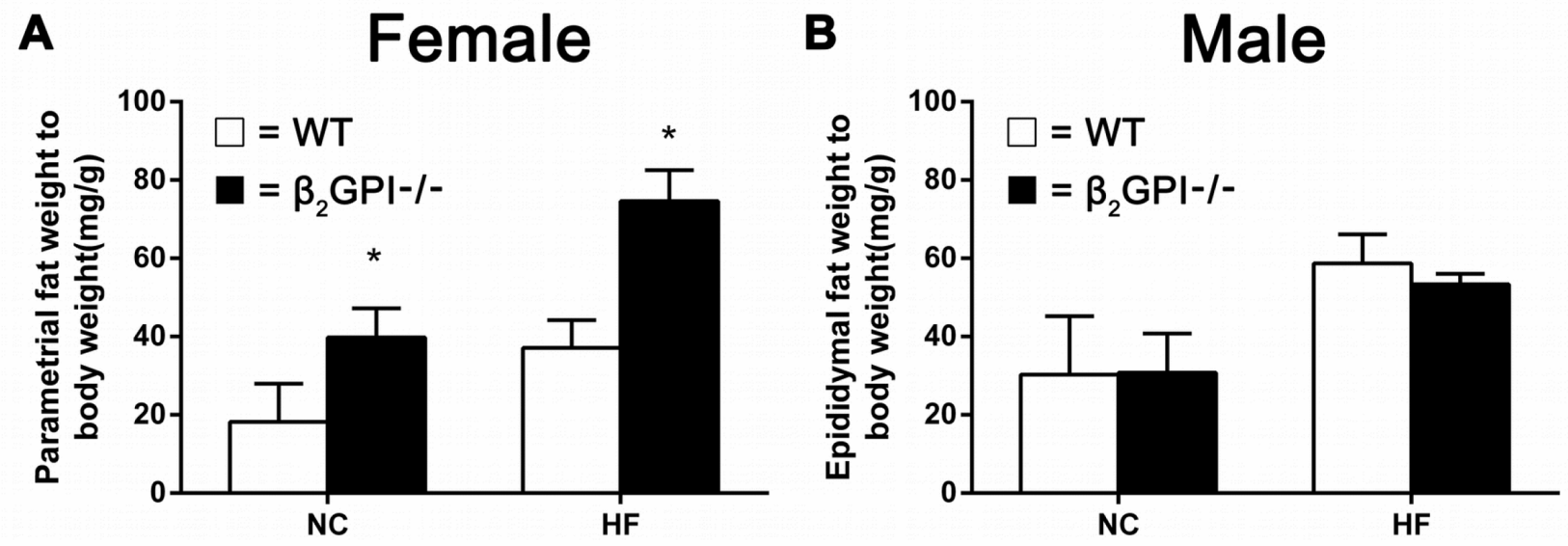

Figure 2: VAT weight in $\beta 2$ GPI-/- mice fed NC or HF diet for 16 weeks. (A) Female; (B) male. $\square=$ WT, $\square=\beta 2 \mathrm{GPI} /-$. Data are expressed as mean $\pm \mathrm{SD}\left(\mathrm{n}=4-5\right.$ mice per group). ${ }^{*} \mathrm{p}<0.05 . \mathrm{NC}=$ normal chow, $\mathrm{HF}=$ high fat. 
A

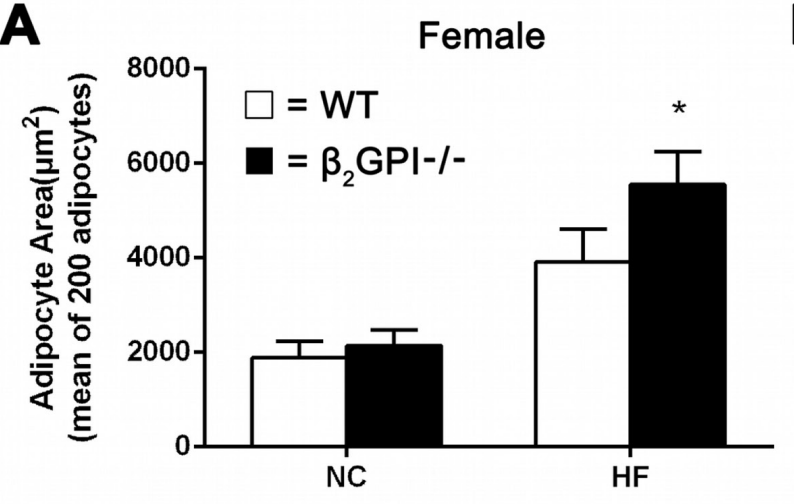

B
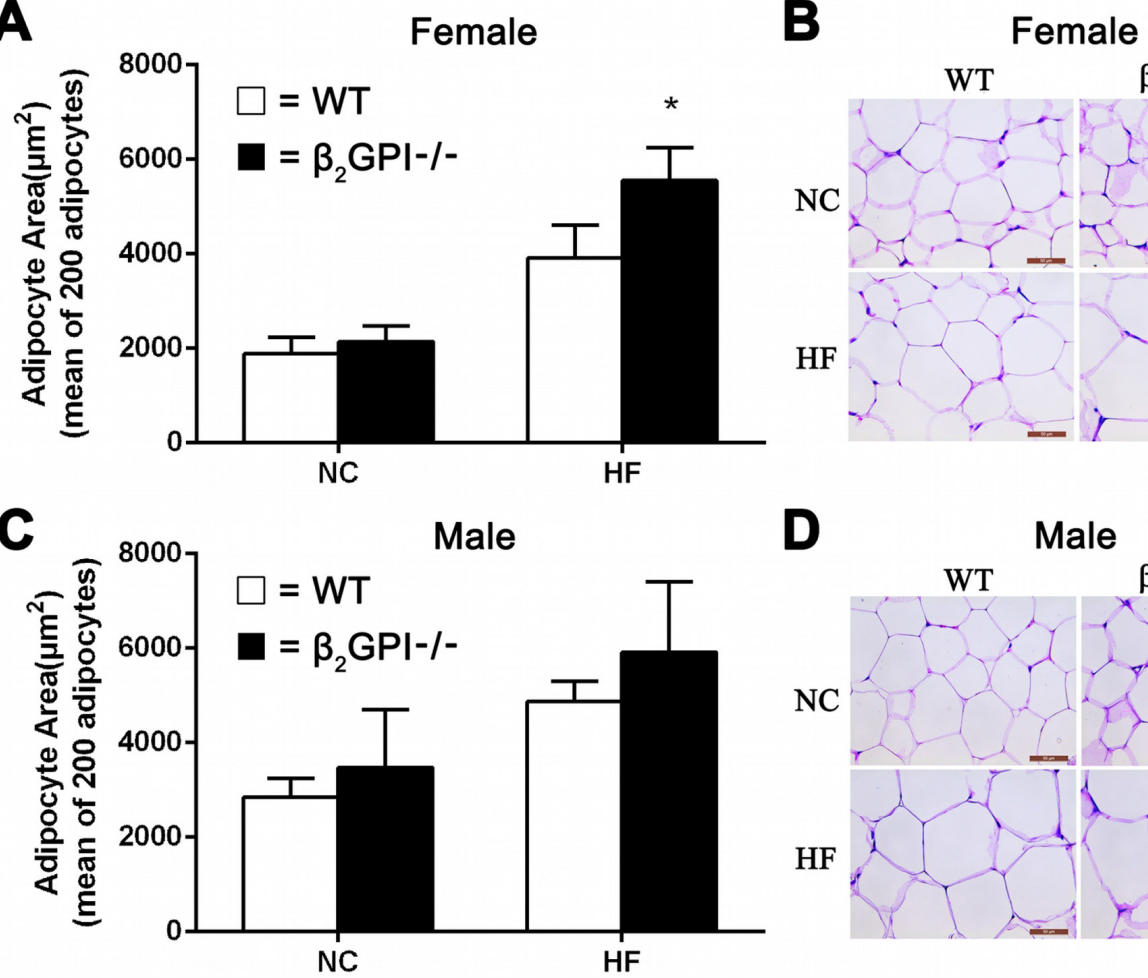

$\mathbf{E}$

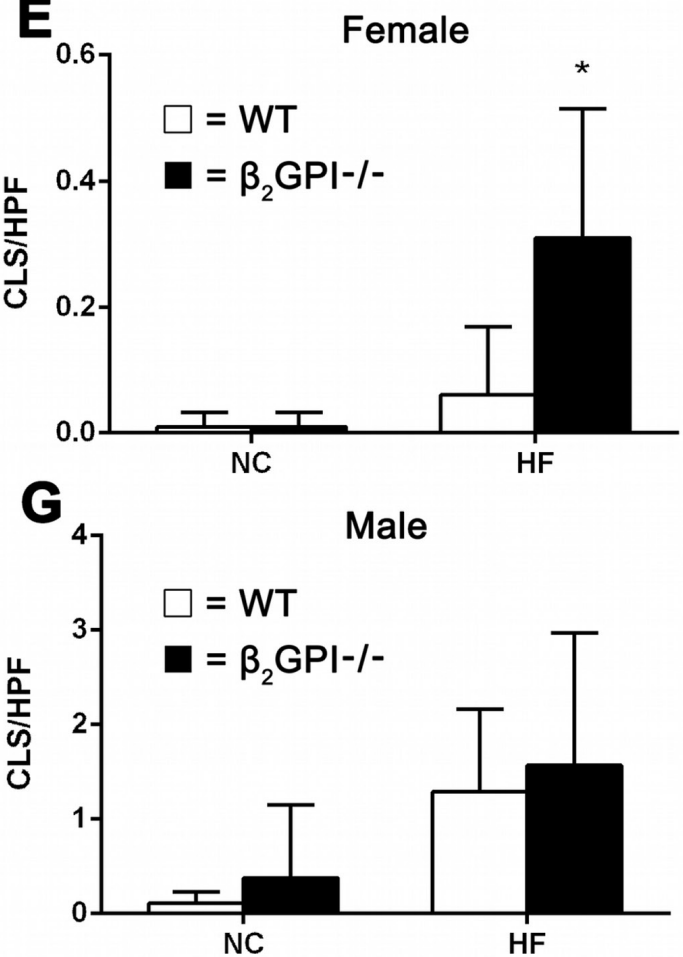

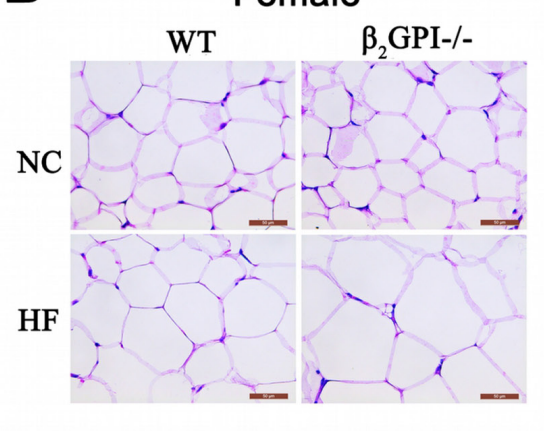

D Male
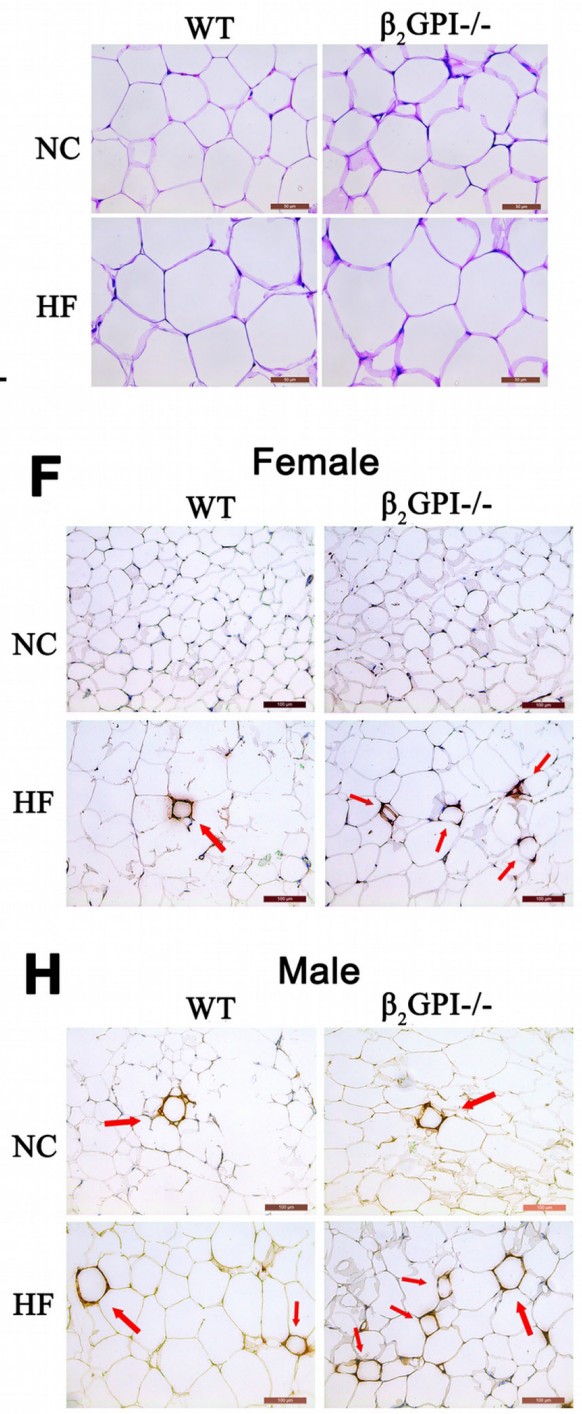

Figure 3: Visceral adipocyte size and infiltration of VAT detected by MAC-2 staining in B2GPI-/- and WT mice fed NC or HF diet for 16 weeks. Female (A, B) and male (C, D) adipocyte area and representative images of adipocyte morphology. Female (E, F) and male (G, H) crown-like structures (CLS) per high power field and representative images of macrophage infiltration of VAT. Scale bar is $50 \mu \mathrm{m}$. Adipocyte area is shown as mean $\pm \mathrm{SD}$ ( $\mathrm{n}=5$ mice per group, 200 cells per mouse). Number of CLS indicated by arrows in VAT was calculated as numbers per high power field in 20 high-power fields (magnification $200 \times$ ). ${ }^{*} \mathrm{p}<0.05$. $\square=\mathrm{WT}, \boldsymbol{\square}=\beta 2 \mathrm{GPI}-/-, \mathrm{NC}$ $=$ normal chow, $\mathrm{HF}=$ high fat. 
the phosphorylation of Atpcl (Ser 455) in the female WT mice fed a HF diet compared to the female WT mice fed $\mathrm{NC}$ (Figure 4A, 4C). In the female $\beta 2 \mathrm{GP}-/-$ mice fed NC there was increased protein expression of FAS, Acc and Atpcl compared to female WT mice fed NC (Figure 4A, 4D), but there was no difference in the p-Acc (Ser79/Acc) and p-Atpcl (Ser455) (Figure 4A, 4E). The lipogenesis enzymes demonstrate an increase in total FAS protein (Figure 4A, 4F) and a decrease in Acc phosphorylation of Ser79 respectively (Figure 4A, 4G) in the female $\beta 2 \mathrm{GP}-/-$ mice fed a HF diet compared to female WT mice fed a HF diet.

\section{In both male and female WT mice lipolysis enzymes were inhibited by HF diet. $\beta 2$ GPI had an effect on the levels of a number of lipolysis enzymes in both females and males}

Lipolysis in VAT is principally regulated by two lipases, adipose triglyceride lipase (Atgl, encoded by Pnpla2), which hydrolyzes the first ester bond of triglycerides, and hormone-sensitive lipase (Hsl, encoded by Lipe), which favors diacylglycerides [24]. Hsl is known to have three major phosphorylation sites. Activated protein kinase A (PKA) phosphorylates Hsl at Ser563 and Ser660, which stimulates Hsl activity [25]. In contrast, AMP-activated protein kinase (AMPK) phosphorylates Hsl at Ser565, which reduces Hsl phosphorylation at Ser563 by PKA and inhibits Hsl activity [25]. Female WT mice fed a HF diet had a significant decrease of Hsl and p-Hsl (Ser563), p-Hsl (Ser660) and p-Hsl (Ser565) compared to female WT fed NC diet (Figure 5A, 5B, 5C). Whereas Pck1 and the lipolysis enzymes Pnpla2 and Lipe were no different (Figure 5D). In the WT male mice fed a $\mathrm{HF}$ diet compared to the WT male mice fed a NC diet there was decreased Hsl levels and the p-Hsl (Ser563), whereas there was no change in p-Hsl (Ser660) and p-Hsl (Ser565) (Figure 5B, 5C). Pck1 and the lipolysis enzymes Pnpla2 and Lipe are significantly decreased in male WT mice fed $\mathrm{HF}$ diet compared to male WT mice fed NC (Figure 5D).

We found that female $\beta 2 \mathrm{GPI} /-$ mice fed $\mathrm{NC}$ diet compared to female WT fed NC had decreased phosphorylation of Hsl on Ser563 and Ser660, but had no effect on phosphorylation of Ser565 in VAT (Figure 5E, 5F). Extracellular signal regulated kinase (Erk) has previously been shown to stimulate lipolysis and Hsl [26]. There was no difference in the levels of total and phosphorylated Hsl and Erk (1/2) in the VAT of female $\beta 2 \mathrm{GPI}-/-$ and female WT mice fed a HF diet (Figure 5A).

Net lipolysis is an equilibrium state between triglyceride breakdown and fatty acid re-esterification. The latter requires glycerol-3-phosphate, the product of glyceroneogenesis, for which the key enzyme is phosphoenolpyruvate carboxykinase (Pepck, encoded by Pck1) [20]. Our results show that female $\beta 2$ GPI-/- mice had markedly decreased expression of Pck1 in VAT when fed a HF diet (Figure 5G). There was no difference in the mRNA levels of the Pnpla2 and Lipe in VAT of female $\beta 2$ GPI-/- and WT mice fed NC or HF diet (data not shown) $(\mathrm{p}>0.05)$.

We examined the lipolysis enzyme Hsl and the phosphorylation at Ser563, 565 and 660, in male NC and HF fed mice. There was no significant difference between diet matched male $\beta 2 \mathrm{GPI} /$ - and WT mice, $\mathrm{p} \geq 0.05$ (data not shown). But there was a decrease in the mRNA levels of Pnpla2 (1.32 \pm 0.45 , mean $\pm \mathrm{SD}, \mathrm{n}=5, \mathrm{p}<0.01$,) in the $\beta 2 \mathrm{GPI}-/-$ male mice compared to the WT males fed a $\mathrm{NC} \operatorname{diet}(2.67 \pm 1.37$, mean $\pm \mathrm{SD}, \mathrm{n}=5)$. There was also a decrease in the mRNA level of Lipe in $\beta 2 \mathrm{GPI} /-$ - male mice fed a HF diet $(0.81 \pm 0.07$, mean $\pm \mathrm{SD}, \mathrm{n}=5, \mathrm{p}<0.01)$ compared to male WT mice fed a HF diet $(1.15 \pm 0.21$, mean $\pm \mathrm{SD}, \mathrm{n}=5$ ).

\section{Female $\beta 2$ GPI-/- mice fed a NC diet demonstrate a decreased food intake}

Food intake in female $\beta 2 \mathrm{GPI}-/-$ mice, compared to female WT mice, was significantly reduced when fed a NC diet (Figure 6A). However no difference in food intake was observed when female mice were given a HF diet (Figure 6A). There was no difference in the male WT and male $\beta 2 \mathrm{GPI} /-$ mice fed either a NC or HF diet (Figure 6B).

\section{Circulating leptin levels in female mice}

Female $\beta 2 \mathrm{GPI} / \mathrm{-}$ mice had an increased plasma leptin level compared to female WT mice fed a NC diet $(\mathrm{p}<0.05)$ (Figure 7). There was a trend showing an increase of leptin levels in female $\beta 2 \mathrm{GPI} /$ - mice fed a HF diet compared to WT females fed a high fat diet, but it did not reach statistical significance (Figure 7).

\section{Quantitation of leptin receptor protein levels in the hypothalamus of female mice}

There is no difference in leptin receptor levels between female $\beta 2 \mathrm{GPI}-/-$ and diet matched female WT mice (data not shown) $(\mathrm{p}>0.05)$.

\section{The effect of $\beta 2$ GPI deficiency on hypothalamus appetite signaling pathways in female mice}

Intact Signal transducer and activator of transcription 3 (STAT3) signaling in the hypothalamus is an important regulator of food intake and has been implicated in mediating a role in leptin's anorectic functions [27]. Malonyl-CoA, an intermediate in fatty acid synthesis, serves as an indicator of energy status in the hypothalamic neurons [28]. Increased hypothalamic malonyl-CoA suppresses food intake [28]. The cellular malonyl-CoA 
level is determined by its rate of synthesis, catalyzed by Acc, and rate of removal by FAS [28]. Malonyl-CoA levels are also under the control of AMP kinase which phosphorylates/inactivates Acc [29]. Hypothalamic Acc activation is an important contributor to leptin's anorectic actions [30]. Inactivation of hypothalamic FAS protects mice from diet induced obesity [31].
We examined the total and phosphorylated levels of STAT3, Erk1/2, and Acc and the total level of FAS and Suppressor of cytokine signalling 3 (SOCS3) in the hypothalamus of female mice fed $\mathrm{NC}$ or $\mathrm{HF}$ diet at 16 weeks. In NC fed mice there was no difference between $\beta 2 \mathrm{GPI} /-$ and WT mice in total STAT3 levels (Figure $8 \mathrm{~A}, 8 \mathrm{~B})$. There was a statistically significant increase in

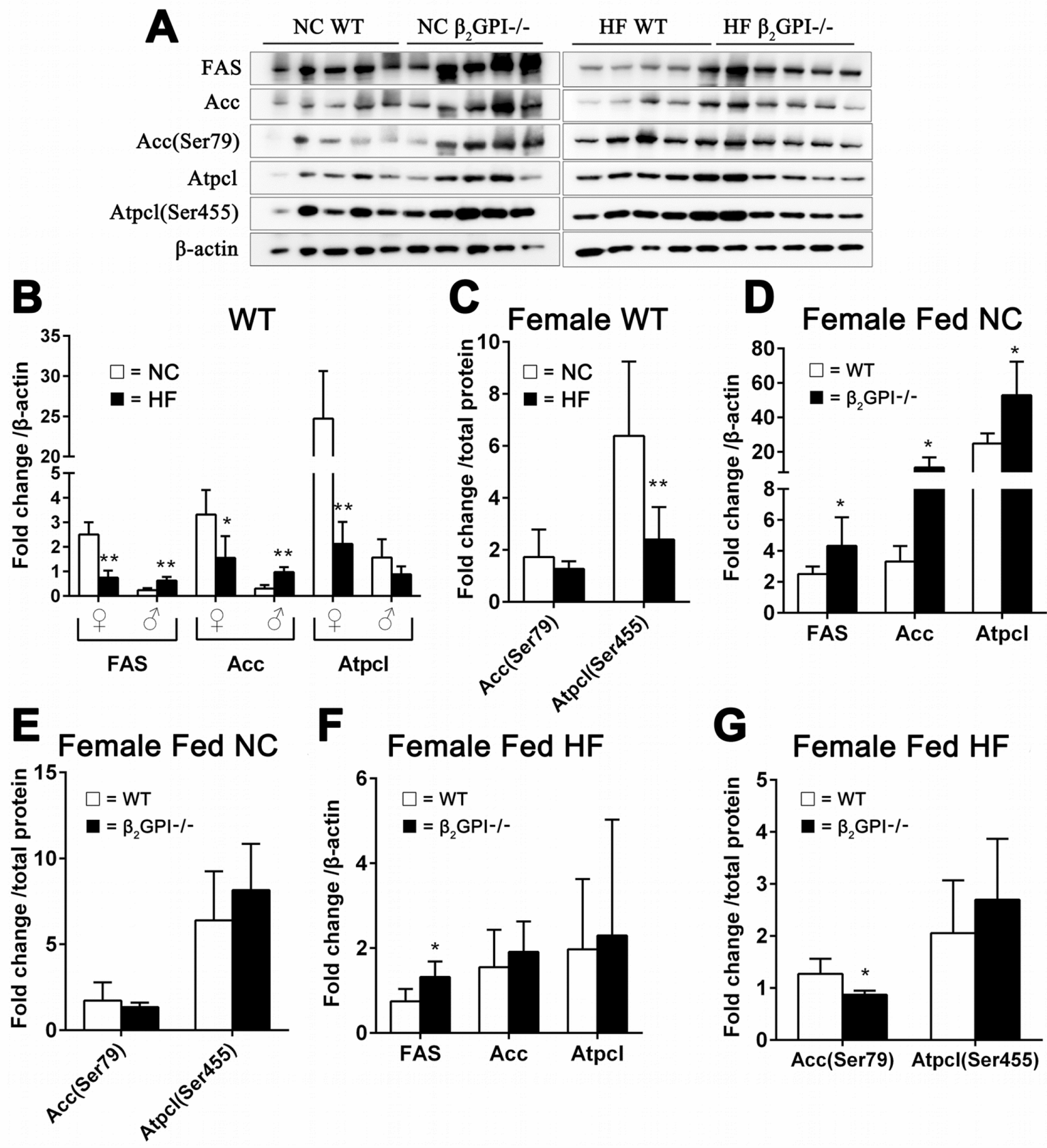

Figure 4: Effect of $\beta 2$ GPI deficiency on VAT lipogenesis enzyme levels. (A) Western blot analysis of VAT proteins. Quantification of the scanned images normalized to $\beta$-actin $(\mathbf{B}, \mathbf{D}, \mathbf{F})$ and to total protein $(\mathbf{C}, \mathbf{E}, \mathbf{G})$. Panels (B) WT mice fed a HF diet compared to WT mice fed NC. $\square=\mathrm{NC}, \mathbf{\square}=\mathrm{HF}$ diet. $q=$ female, $\hat{\sigma}=$ male. (C) Phosphorylation of Acc (Ser79) and Atpcl (Ser 455) as a ratio of the total protein level from (B) for female mice. $\square=\mathrm{NC}$ diet, $\boldsymbol{\square}=\mathrm{HF}$ diet. (D) Female $\beta 2 \mathrm{GPI}-/$ - mice fed a NC diet compared to female WT mice fed a NC diet. $\square=$ WT, $\mathbf{\square}=\beta 2 \mathrm{GPI}-/-$. (E) p-Acc (Ser79/Acc) and p-Atpcl (Ser455). (F) Fas Protein, Acc and Atpcl. (G) Phosphorylation of Acc (Ser79) and Atpcl (Ser455) as a ratio to the total protein level from (F). $\square=$ WT, $\square=\beta 2 \mathrm{GPI}-/$-. 
p-STAT3 (Tyr705) in female $\beta 2 \mathrm{GPI}-/$ - compared to female WT mice fed NC (Figure 8A, 8C). SOCS3 an inhibitor of STAT3 [32] was significantly downregulated in the female $\beta 2$ GPI-/- mice fed a NC diet when compared to female WT mice fed a NC diet (Figure 8A, 8D). Hypothalamic Erk1/2 is a member of the MAPK family and is an additional downstream pathway of the leptin receptor, and plays a role in food intake, body weight and thermogenic sympathetic outflow [33]. Total and phosphorylated levels of Erk1/2 were not different in diet matched female $\beta 2 \mathrm{GPI}-/-$ and female WT mice (data not shown). In the female $\beta 2 \mathrm{GPI}-/$ - compared to female WT mice fed a NC diet there was a decrease in the level of phosphorylated Acc (Ser79) and a decrease in the total level of FAS (Figure 8A, 8E-8G). In contrast in the HF diet fed female mice, there was no significant difference in any of the described enzyme levels between WT and $\beta 2 \mathrm{GPI}-/$ - female mice (Figure 8A-8G).
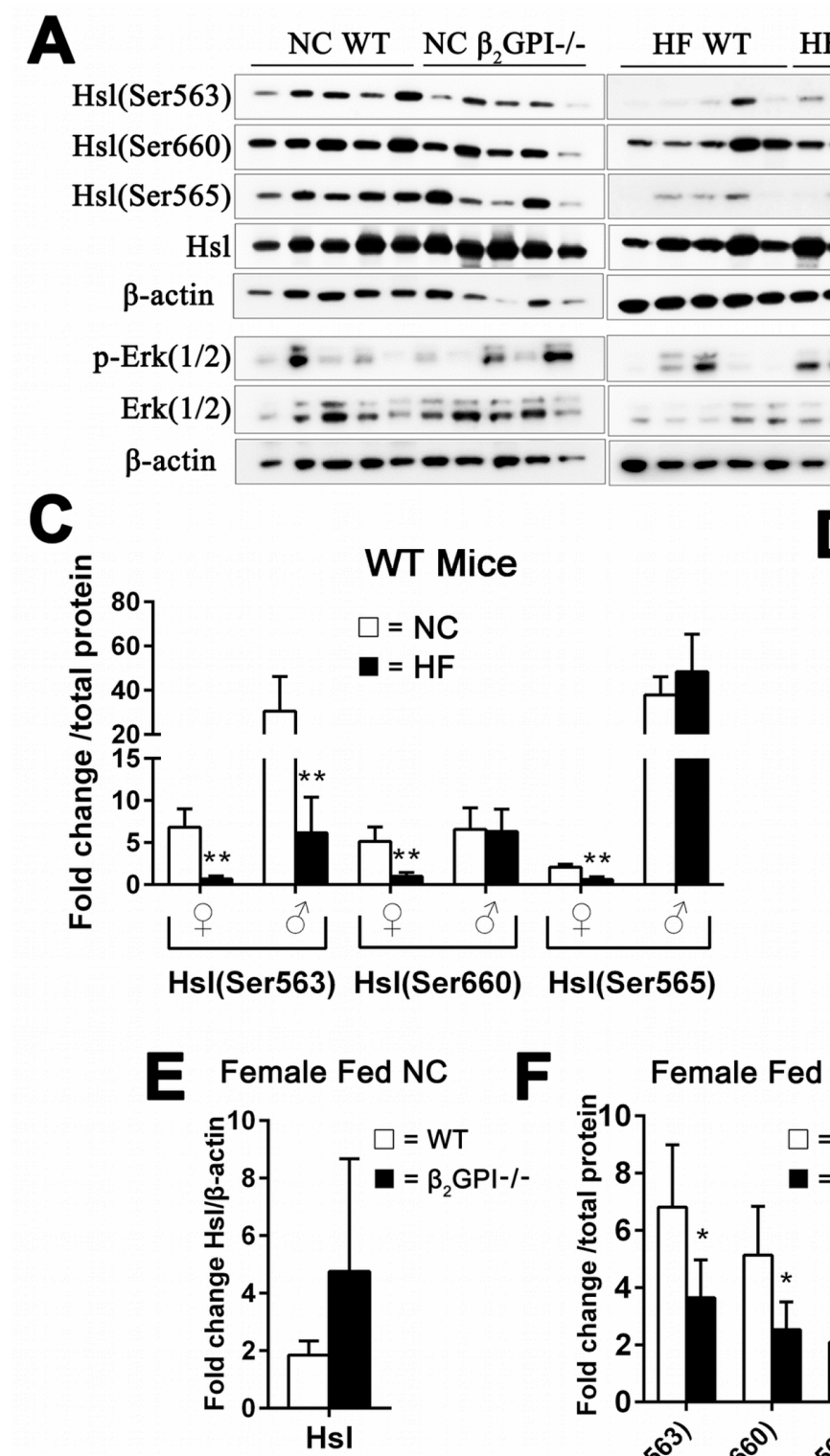

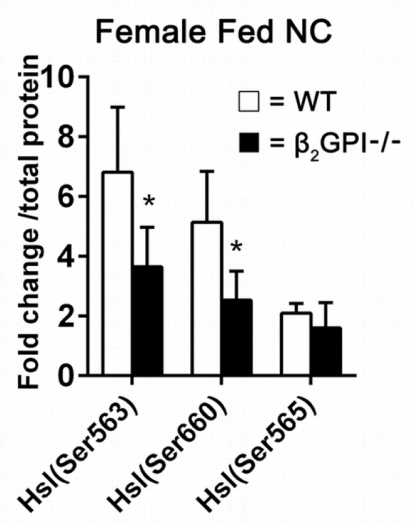

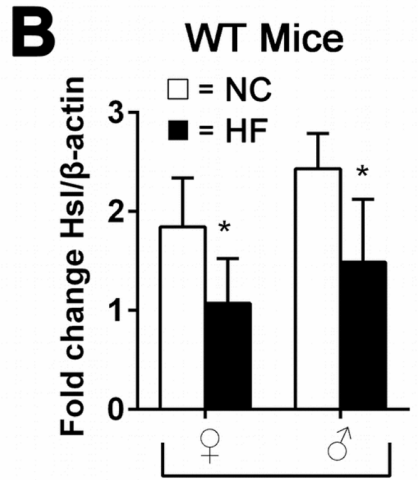

Hsl

D

WT Mice
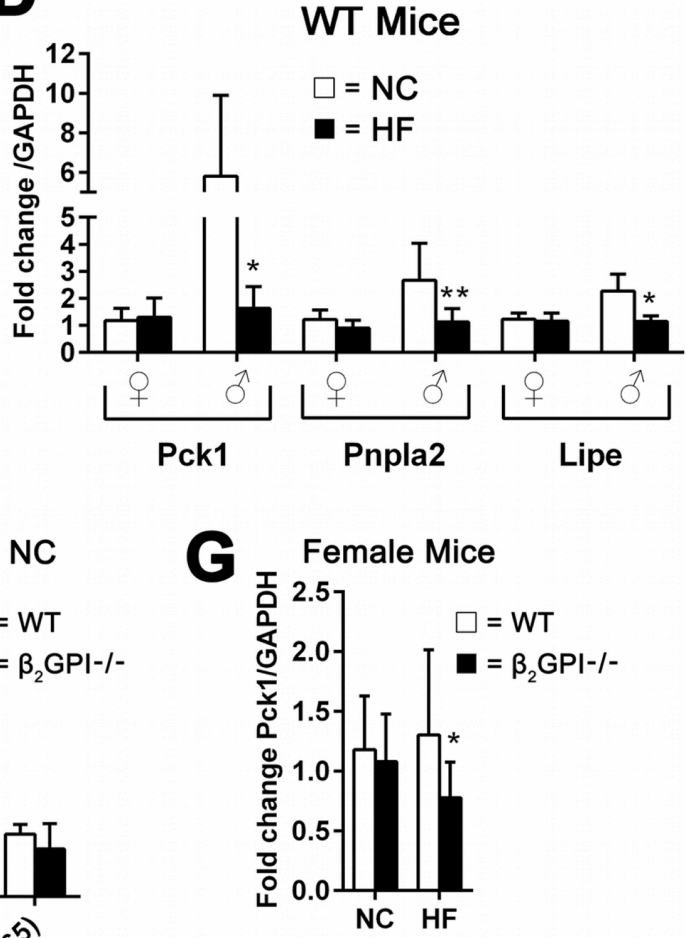

Figure 5: Effect of $\beta 2$ GPI deficiency on VAT lipolysis enzyme activation. (A) Western blot analysis of lipolysis enzymes in VAT of female mice. (B) Hsl - total and (C) is phosphorylation of Hsl (Ser563), Hsl (Ser660) and Hsl (Ser565). $\square=$ NC diet, $\boldsymbol{\square}=$ HF diet. (D) mRNA levels of Pck1, Pnpla2 and Lipe. $\square=\mathrm{NC}$ diet, $\boldsymbol{\square}=$ HF diet. $q=$ female, $\widehat{\sigma}=$ male. (E) Total Hsl and (F) phosphorylated Hsl (Ser563), Hsl (Ser660) and Hsl (Ser565) in female $\beta 2$ GPI-/- and female WT mice fed a NC diet. $\square=$ WT, $\square=\beta 2$ GPI-/-. (G) mRNA levels for Pck1 in female $\beta 2 \mathrm{GPI}-/-$ and female WT mice fed a NC and HF diet. $\square=\mathrm{WT}, \boldsymbol{\square}=\beta 2 \mathrm{GPI}-/-$. 

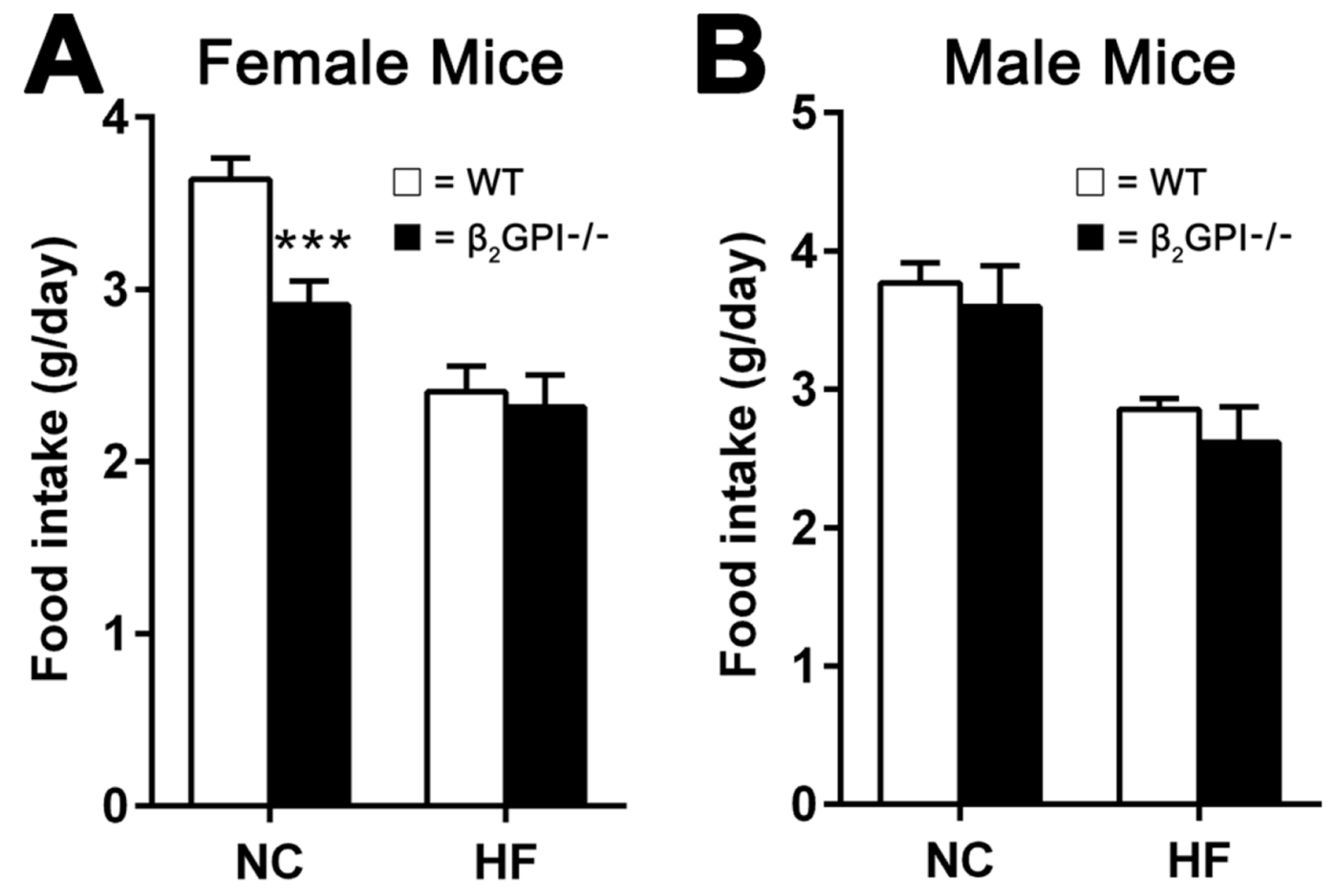

Figure 6: Daily food intake per mouse when fed NC or HF diet for 16 weeks. (A) Female; (B) male, $\square=$ WT, $\square=\beta 2 \mathrm{GPI} /-$. Data are expressed as mean $\pm \mathrm{SD}, \mathrm{n}=4-5$ mice per group. ${ }^{* * *} \mathrm{p}<0.001 . \mathrm{NC}=$ normal chow, $\mathrm{HF}=$ high fat.

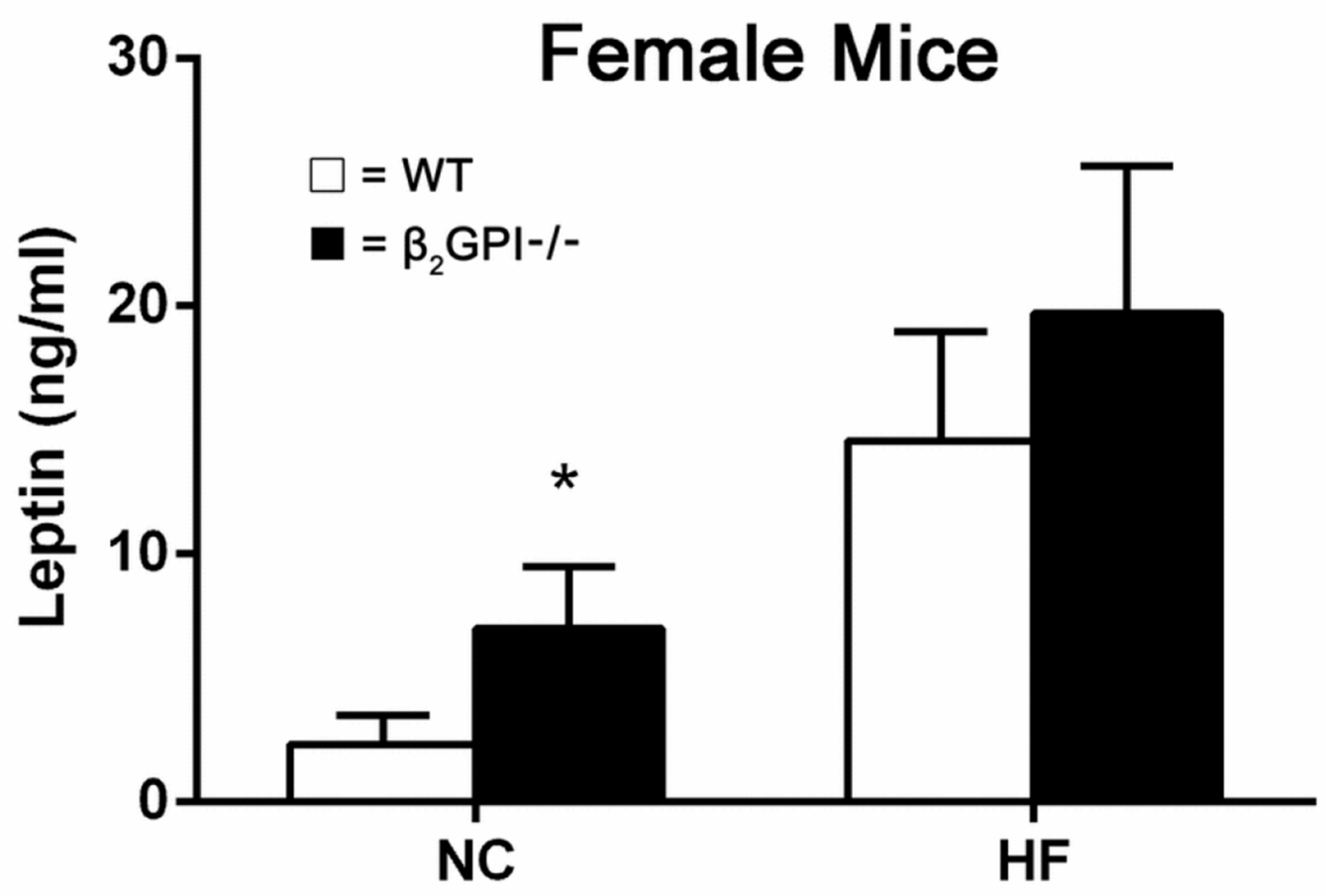

Figure 7: Plasma leptin levels in female $\beta 2$ GPI-/- and WT mice fed NC or HF diet. $\square=$ WT, $\square=\beta 2$ GPI-/-. Data are expressed as mean $\pm \mathrm{SD}\left(\mathrm{n}=5\right.$ mice per group). ${ }^{*} \mathrm{p}<0.05 . \mathrm{NC}=$ normal chow, $\mathrm{HF}=$ high fat. 

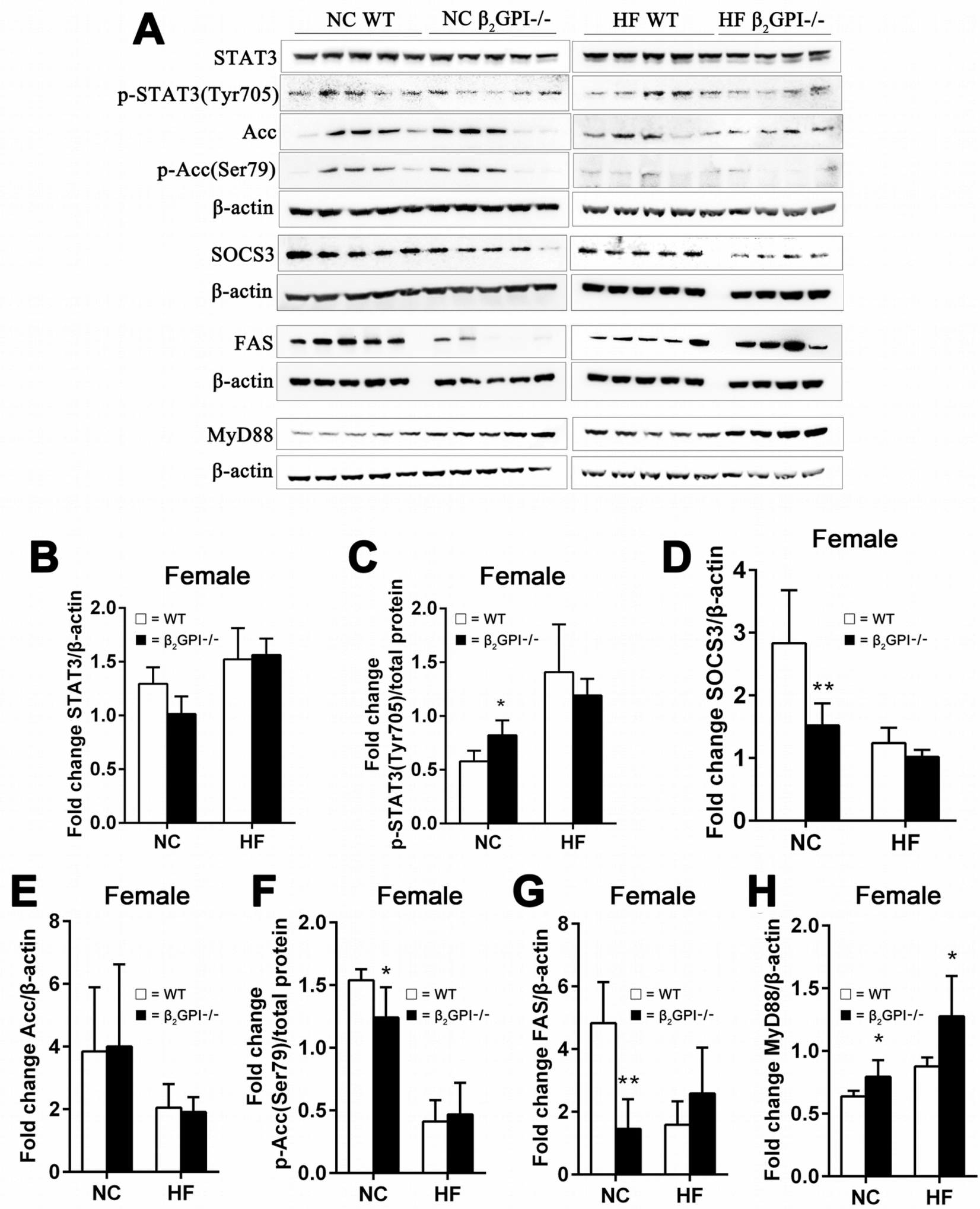

Figure 8: $\beta 2$ GPI deficiency and the hypothalamic appetite signaling pathways. (A) Western blot analysis of hypothalamic proteins in female mice. (B-H) quantification of the immunoreactive bands (B) STAT3, (C) p-STAT3 (Tyr705) (D) SOCS3, (E) Acc, (F) p-Acc(Ser79), (G) FAS/ $\beta$-actin and (H) MyD88. $\square=\mathrm{WT}, \boldsymbol{\square}=\beta 2 \mathrm{GPI}-/-, \mathrm{NC}=$ normal chow, $\mathrm{HF}=$ high fat. Data are expressed as mean \pm $\mathrm{SD}\left(\mathrm{n}=4-5\right.$ mice per group). ${ }^{*} \mathrm{p}<0.05 .{ }^{* *} \mathrm{p}<0.01$. 
Increased MyD88 signalling in the hypothalamus has been found to contribute to fatty acid induced leptin resistance and diet induced obesity [34]. In the female $\beta 2 \mathrm{GPI}-/$ - mice compared to the female WT mice, both for $\mathrm{NC}$ and HF diet fed mice, there is increased MyD88 in the hypothalamus $(\mathrm{p}<0.05)$ (Figure $8 \mathrm{~A}, 8 \mathrm{H})$.

\section{There is no difference in glucose tolerance test in WT and B2GPI deficient mice fed a high fat diet}

Male and female WT and $\beta 2$ GPI deficient mice did not display any difference in blood glucose levels over 125 min following a glucose tolerance challenge test after overnight fasting (Figure 9A, 9B).

\section{DISCUSSION}

In this paper we describe that female mice deficient in $\beta 2 \mathrm{GPI}$ are more prone to visceral fat accummulation compared to WT females when fed either a normal chow or high fat diet. Analysis of the visceral adipose tissue was consistent with a process of increased lipogenesis in the female $\beta 2$ GPI -/- mice fed either a normal or high fat diet diminished lipolysis in the female $\beta 2 \mathrm{GPI}$-/- mice fed NC diet.

In the setting of being fed a normal chow diet, the female 32 GPI -/- mice appear to have a compensatory decreased satiety response, driven by increased leptin levels, leading to increase in the anorexic signalling pathways of the hypothalamus including activation of STAT3. Female $\beta 2$ GPI -/- mice fed a high fat diet do not have a compensatory decrease in their satiety response. Despite an increase in visceral fat deposition, they consumed on a weekly basis an equivalent amount of high fat diet to their WT counterparts, and hence gained significantly more weight. The high fat diet fed female $\beta 2$ GPI -/- mice had a trend towards elevated leptin levels in their plasma, raising the possibility of them having increased resistance to the central anorexogenic actions of leptin in the hypothalamus. Though STAT3 and Acc signalling in the hypothalamus was equivalent between the female $\beta 2$ GPI deficient mice and the female WT mice fed a high fat diet, the former had increased levels of hypothalamic MyD88 which has been implicated as contributing to leptin resistance in the setting of mice been fed a high fat diet [34]. As a point of contrast, in male mice, fed either a normal chow or high fat diet, $\beta 2$ GPI deficiency does not influence weight gain, VAT accumulation and lipogenesis enzymes in the VAT compared to WT male controls. This indicates that $\beta 2 \mathrm{GPI}$ regulates fat metabolism in mice in a sexually dimorphic manner.

We noted WT females when fed a HF diet were protected from early onset obesity until 12 weeks of feeding. In male WT mice this early protective effect is not seen and the HF fed mice gain more weight than WT males fed NC within the first week. This phenomenon has previously been reported and as far as we are aware no mechanism has been described to explain this sexually dimorphic response $[10,35]$. If we assume that weight gain is due to energy storage as reflected by lipogenesis activity, whilst lipolysis reflects fat breakdown, then our results showing down regulation of the lipogenesis proteins in the WT females fed a high fat diet when compared to WT females fed NC, suggest that WT females are protected from early onset obesity due to down regulation of the lipogenesis pathways. If the lipolysis pathways were contributing to this protective effect we would have

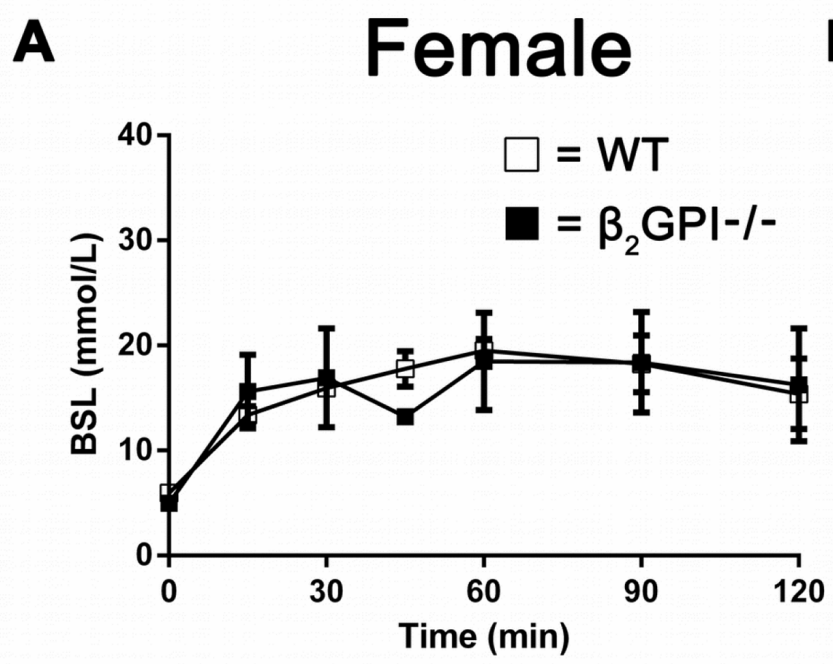

B $\quad$ Male

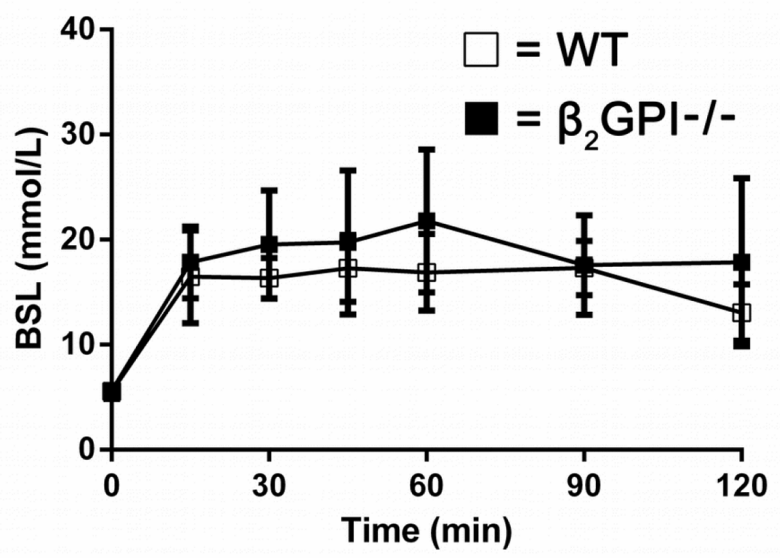

Figure 9: Effect of a glucose tolerance challenge on plasma glucose in WT and $\beta 2$ GPI deficient mice fed a high fat diet. (A) Female mice. (B) Male mice. Blood glucose levels were measured over 125 min after intraperitoneal injection of glucose. $\square=$ WT, $\square$ $=\beta 2$ GPI deficient mice. 
expected to see their upregulation in WT females fed HF, whereas in contrast we saw that the lipolysis proteins were down regulated. Female $\beta 2 \mathrm{GPI}-/$ - mice fed a HF diet lost this early protective anti-obesity effect seen in WT females fed a HF diet, and they gained significantly more weight starting within the first week when fed a HF diet. They had a significant increase in the protein expression of the lipogenesis enzyme FAS and decreased phosphorylation of Acc (Ser79) compared to WT females fed a HF diet. This suggests that a mechanism by which $\beta 2$ GPI mediates its protective anti-obesity effect in females is by inhibiting the lipogenesis process from occurring in VAT. However, $\beta 2 \mathrm{GPI}$ also promotes lipolysis in VAT of females fed a NC diet and this may also contribute to its anti-obesity effect in female mice.

It has been noted in a previous study that exposure to a high fat diet for 12 weeks led to greater weight gain in $\mathrm{C} 57 \mathrm{BL} / 6 \mathrm{~J}$ males compared to age matched females [35]. This study noted that inflammatory genes were upregulated in males when compared to females, and there was a partial reversal after oophorectomy, where it was noted that weight gain and adipose tissue gene expression was more 'male like' [35]. It is therefore relevant to note that in our study, $\beta 2$ GPI deficient females, whether fed a normal chow or high fat diet had an increase in their intraabdominal/gonadal tissue fat compared to WT females. Furthermore, $\beta 2$ GPI deficient females fed a high fat diet had an increase in their systemic inflammatory response as well as macrophage infiltration of VAT. These findings suggest that in the absence of $\beta 2$ GPI female mice acquire a more 'male like' fat distribution phenotype and an accompanying inflammatory response.

Recently it has been noted that $\beta 2 \mathrm{GPI}$ is able to attenuate lipopolysaccharide (LPS)/endotoxin induced signaling through Toll-like receptor 4 (TLR4) by a mechanism involving diverting the $\beta 2$ GPI-LPS complex to bind instead to low-density lipoprotein receptor-related protein 8 (cell surface receptor also known as ApoER2) [36], suggesting this receptor related mechanism may be involved in modulating fat storage in the $\beta 2 \mathrm{GPI}$ deficient compared to the wild-type female mice. Low grade endotoxemia has been well documented to contribute to the obesity promoting effects of a high fat diet through complex mechanisms [37, 38]. The finding of elevated CRP and macrophage infiltration in the VAT in female $\beta 2$ GPI -/- mice fed a high fat diet, as well as increased levels in the hypothalamus of MyD88 in NC and high fat diet fed female $\beta 2$ GPI -/- mice supports the possibility of increased gut derived LPS mediated systemic signaling through the TLR4/MyD88 pathway in the absence of $\beta 2 \mathrm{GPI}$. The activation of the TLR4/MyD88 pathway disrupts the ability of adipose tissue known as 'beige fat' to switch towards brown fat, hence promoting the energy conserving, fat storage white adipose tissue phenotype [39]. Studies in rodents have shown that beige adipocytes are flexible being able to convert between brown and white phenotype [40]. Such regulatory signaling within beige fat has been implicated as being disrupted with the FTO obesity variant in humans, promoting a pro-obesity phenotype [4]. In this regard the recently described association between specific $\beta 2$ GPI and FTO SNPs conferring a benefit towards a healthy leanness phenotype is relevant [17]. We speculate $\beta 2$ GPI may promote leanness by maintaining the brown fat phenotype by inhibiting activation of the TLR4/MyD88 pathway in adipose tissue, though further study is necessary regarding this hypothesis.

In summary our findings support a role of $\beta 2 \mathrm{GPI}$ in preventing fat deposition in visceral fat and an accompanying systemic inflammatory response in females. The precise mechanism remains to be delineated.

\section{MATERIALS AND METHODS}

\section{Animals and diet}

C57BL/6J WT mice and $\beta 2 \mathrm{GPI}-/-$ mice on a C57BL/6J background were used in this study [41]. All animal experimental protocols were approved by the UNSW Animal Care and Ethics Committee. All mice were group housed in the animal house, St George Hospital, University of New South Wales, at $20+/-2{ }^{\circ} \mathrm{C}$ on a 12/12-hour dark-light cycle and had ad libitum access to water and food. Eight-week-old animals $(n=5)$ for each genotype, diet and sex were randomly allocated into 8 groups (female WT, NC and HF; female $\beta 2 \mathrm{GPI} /-\mathrm{NC}$ and HF; male WT, NC and HF; male $\beta 2$ GPI-/- NC and $\mathrm{HF}$ fed animals) in order to test the influence of genotype, diet and sex on weight gain. NC, was from Gordon's Specialty Stockfeeds, Yanderra, NSW, Australia while the HF, SF00-219 was from Specialty Feeds, Glen Forest, Western Australia, Australia and contained $19.4 \mathrm{~kJ} / \mathrm{g}$; energy $40 \%$ fat, $17 \%$ protein, $43 \%$ carbohydrate. The mice were weighed weekly and food intake was measured initially then weekly by monitoring the weight of the remaining food and the mice were sacrificed after 16 weeks of dietary treatment. At the time of sacrifice mice were fasted overnight for $10-14 \mathrm{~h}$ and anesthetized by isoflurane inhalation.

\section{Sample collection}

Blood samples were collected by cardiac puncture in $1 \mathrm{~mL}$ tubes containing K3 EDTA (Greiner Vacuette Minicollect K3 EDTA tube; Greiner Bio-one $\mathrm{GmbH}$, Kremsmünster, Austria). They were centrifuged (1,000 g for $10 \mathrm{~min}$ ) and the subsequent plasma fraction collected and stored at $-80^{\circ} \mathrm{C}$ until use. Female and male, WT and $\beta 2 \mathrm{GPI}-/-$ mice were perfused with phosphate-buffered saline (PBS) through the left ventricle following cardiac puncture for blood collection. After the female mice were euthanized, the whole hypothalamus was surgically 
excised and snap frozen in liquid nitrogen. Female and male WT and $\beta 2$ GPI-/- mice fed NC and HF diets had their VAT (parametrial/epididymal) removed, weighed and divided in three parts, one was added to RNA stabilisation agent (Qiagen, Hilden, Germany), one was directly snap frozen and both were stored in liquid nitrogen at $-80^{\circ} \mathrm{C}$ and the third portion was fixed in $10 \%$ neutral buffered formalin until analysed.

\section{ELISA assays}

ELISAs for quantitating leptin were from Merck Millipore (Bedford, MA) and CRP was from (R\&D Systems, Minneapolis, MN). Levels were quantitated following the manufacturer's instructions.

\section{RNA isolation, cDNA synthesis, and qPCR}

Total RNA from mouse VAT specimens was extracted with the RNeasy Lipid Tissue Mini Kit from Qiagen, (Hilden, Germany) according to the manufacturer's instructions. cDNA was obtained by reverse transcribing the total RNA with a QuantiTect Reverse Transcription Kit (Qiagen). Amplification and analysis were performed on the Bio-Rad CFX96TM Real-Time PCR System (Bio-Rad, Hercules, CA). The primers were from Qiagen for all target genes. GAPDH was used as an internal control, and target gene values were normalized to those of GAPDH. Relative mRNA expression levels were calculated using a comparative $\Delta \Delta \mathrm{Ct}$ method. $\Delta \mathrm{Ct}$ (experimental) $=\mathrm{Ct}$ (target gene) - $\mathrm{Ct}(\mathrm{GAPDH}), \Delta \mathrm{Ct}$ (control) $=\mathrm{Ct}$ (target gene) $-\mathrm{Ct}$ $(\mathrm{GAPDH}), \Delta \Delta \mathrm{Ct}=\Delta \mathrm{Ct}$ (experimental) $-\Delta \mathrm{Ct}$ (control), then the fold-change in gene expression was derived by $2-\Delta \Delta \mathrm{Ct}$.

\section{Quantitation of proteins in VAT and hypothalamus by western blotting}

VAT was homogenised in radioimmunoprecipitation assay buffer containing $1 \%$ protease and 1\% phosphatase inhibitor cocktails (Sigma-Aldrich, St Louis, MO) centrifuged at $12,000 \mathrm{~g}$ for $15 \mathrm{~min}$, and the supernatant was harvested while carefully avoiding the lipid layer on top. Protein concentration was measured with a BCA protein quantification kit (Thermo Fisher Scientific, San Jose, CA). Protein extracts were separated on a $4-12 \%$ NuPAGE gel (Thermo Fisher Scientific) and then transferred onto Immobilon FL PVDF membrane (Merck Millipore). Membranes were blocked with 5\% BSA or skim milk at RT for $1 \mathrm{~h}$ and incubated with primary antibodies either FAS, Acc, p-Acc (Ser79), Atpcl, p-Atpcl (Ser455), STAT3, p-STAT3 (Tyr705), SOCS3, Erk1/2, p-Erk1/2 (Thr202/Tyr204), Hsl, p-Hsl (Ser563, Ser660, Ser565), all were from Cell Signaling Technology (Beverly, MA). Antibodies to MyD88 and leptin receptor were from (Abcam, Cambridge, UK) and an antibody to $\beta$-actin was from (Sigma-Aldrich). After three consecutive 5 min washes in Tris-buffered saline-Tween 20 (TBS-T) $(0.1 \%)$ (Sigma-Aldrich), membranes were incubated with rabbit/mouse HRP-conjugated secondary antibodies (DAKO; Glostrup, Denmark) for $1 \mathrm{~h}$ at RT. After three further washes in TBS-T, ECL reagent was added (GE Healthcare, Milwaukee, MI) and incubated for $1 \mathrm{~min}$. The membranes were scanned and the band density quantified with the Image analysis system-ImageQuant LAS4010 and Image Quant software (GE Healthcare, Milwaukee, MI). The relative expression of target $=$ the grey value of target protein/grey value of the housekeeping gene $\beta$-actin. Membranes were stripped with the stripping agent Restore (Thermo Fisher Scientific) according to the protocol of the manufacturer.

\section{Histology and histomorphometry}

Adipose tissues were isolated from either epididymal or parametrial areas and fixed in $10 \%$ neutral buffered formalin. The tissues were then processed for paraffin embedding. Multiple $6 \mu \mathrm{m}$-thick microtome sections from each tissue were stained with H\&E and photographed. For measurement of adipocyte area, 200 adipocytes from each VAT sample were sampled and the area for each adipocyte was calculated and expressed as a mean for each mouse.

\section{Immunohistochemistry}

For immunohistochemical studies, $3-\mu \mathrm{m}$ sections of VAT samples were cut from each specimen and mounted on silane-coated slides. An anti-MAC-2 antibody was from (Cedarlane, Burlington, Canada) and used for macrophage immunolabelling using the streptavidinbiotin-peroxidase complex method, with a commercial detection system (DAKO) following the manufacturer's instructions. Antigen retrieval was by microwave treatment in citrate buffer $(\mathrm{pH}$ 6.0) three times for $5 \mathrm{~min}$ each in a $750 \mathrm{~W}$ microwave oven, followed by cooling for $20 \mathrm{~min}$ at RT. The primary antibody MAC-2 was diluted 1 in 1000 in PBS and applied to the VAT samples for $1 \mathrm{~h}$ at RT. The immunoreaction was visualized by incubation with 3, 3'-diaminobenzidine tetrahydrochloride (DAB) at $0.05 \%$ with $0.01 \% \mathrm{H}_{2} \mathrm{O}_{2}$ as the final substrate for $5 \mathrm{~min}$. After a final washing in distilled water, the sections were counterstained with haematoxylin, dehydrated, cleared and mounted. The primary antibody was replaced by normal goat IgG (R\&D Systems) as negative controls. Positive controls consisted of WT mouse liver tissue for MAC-2.

\section{Glucose tolerance challenge tests}

In selected mice ( $\mathrm{n}=4$ to 5$)$ at the end of the study an intraperitoneal tolerance test was performed in overnight fasted mice as previously described my McGrath et al [42]. 


\section{Statistical analyses}

Statistical analyses were performed using the MannWhitney test. All analyses performed used the GraphPad Prism version 5.01 for Windows (GraphPad Software, La Jolla, California, www.graphpad.com). $\mathrm{P}<0.05$ were considered statistically significant.

\section{Abbreviations}

Acc: acetyl-CoA carboxylase; AMPK: AMPactivated protein kinase; ApoH: apolipoprotein $\mathrm{H}$; Atcpl: ATP citrate lyase; $\beta 2 \mathrm{GPI}$ : $\beta 2$-glycoprotein I; BMI: Body Mass Index; CRP: $\mathrm{C}$ reactive protein; FAS: fatty acid synthase; FTO: Fat Mass and Obesity Associated variant; HF: high fat diet; Hsl: hormone-sensitive lipase; NC: normal chow diet; p-Atpcl: phospho-ATP citrate lyase; PKA: activated protein kinase A; Ser: serine; SOCS3: suppressor of cytokine signalling 3; STAT3: signal transducer and activator of transcription 3; VAT: visceral adipose tissue; WT: wild type.

\section{Author contributions}

Concept and design S.D., S.A.K., B.G., L.C.; Data Acquisition S.D., M.Q., Y.W., J.C.W., B.G.; Analysis and Interpretation S.D., S.A.K., B.G., Y.W.; Drafting Manuscript S.D., S.A.K., B.G., L.C. All authors reviewed the manuscript.

\section{CONFLICTS OF INTEREST}

The authors declare that they have no conflicts of interest with the contents of this article.

\section{FUNDING}

St George and Sutherland Medical Research Foundation. The sponsor or funding organisation had no role in the design or conduct of this research.

\section{REFERENCES}

1. NCD Risk Factor Collaboration (NCD-RisC). Trends in adult body-mass index in 200 countries from 1975 to 2014: a pooled analysis of 1698 population-based measurement studies with 19.2 million participants. Lancet. 2016; 387:1377-96. https://doi.org/10.1016/ S0140-6736(16)30054-X.

2. Di Angelantonio E, Bhupathiraju ShN, Wormser D, Gao P, Kaptoge S, Berrington de Gonzalez A, Cairns BJ, Huxley R, Jackson ChL, Joshy G, Lewington S, Manson JE, Murphy N, et al, Global BMI Mortality Collaboration. Body-mass index and all-cause mortality: individual-participant-data meta-analysis of 239 prospective studies in four continents. Lancet. 2016; 388:776-86. https://doi.org/10.1016/ S0140-6736(16)30175-1.
3. Speliotes EK, Willer CJ, Berndt SI, Monda KL, Thorleifsson G, Jackson AU, Lango Allen H, Lindgren CM, Luan J, Magi R, Randall JC, Vedantam S, Winkler TW, et al. Association analyses of 249,796 individuals reveal 18 new loci associated with body mass index. Nat Genet. 2010; 42:937-48. https://doi.org/10.1038/ng.686.

4. Claussnitzer M, Dankel SN, Kim KH, Quon G, Meuleman W, Haugen C, Glunk V, Sousa IS, Beaudry JL, Puviindran V, Abdennur NA, Liu J, Svensson PA, et al. FTO obesity variant circuitry and adipocyte browning in humans. $\mathrm{N}$ Engl J Med. 2015; 373:895-907. https://doi.org/10.1056/ NEJMoa1502214.

5. Wells JC. Sexual dimorphism of body composition. Best Pract Res Clin Endocrinol Metab. 2007; 21:415-30. https:// doi.org/10.1016/j.beem.2007.04.007.

6. Carey VJ, Walters EE, Colditz GA, Solomon CG, Willett WC, Rosner BA, Speizer FE, Manson JE. Body fat distribution and risk of non-insulin-dependent diabetes mellitus in women. The Nurses' Health Study. Am J Epidemiol. 1997; 145:614-9.

7. Wang Y, Rimm EB, Stampfer MJ, Willett WC, Hu FB. Comparison of abdominal adiposity and overall obesity in predicting risk of type 2 diabetes among men. Am J Clin Nutr. 2005; 81:555-63.

8. Canoy D. Distribution of body fat and risk of coronary heart disease in men and women. Curr Opin Cardiol. 2008; 23:591-8. https://doi.org/10.1097/HCO.0b013e328313133a.

9. Pischon T, Boeing H, Hoffmann K, Bergmann M, Schulze MB, Overvad K, van der Schouw YT, Spencer E, Moons KG, Tjonneland A, Halkjaer J, Jensen MK, Stegger J, et al. General and abdominal adiposity and risk of death in Europe. N Engl J Med. 2008; 359:2105-20. https://doi. org/10.1056/NEJMoa0801891.

10. Yang Y, Smith DL Jr, Keating KD, Allison DB, Nagy TR. Variations in body weight, food intake and body composition after long-term high-fat diet feeding in C57BL/6J mice. Obesity (Silver Spring). 2014; 22:214755. https://doi.org/10.1002/oby.20811.

11. de Groot PG, Meijers JC. beta(2) -glycoprotein I: evolution, structure and function. J Thromb Haemost. 2011; 9:127584. https://doi.org/10.1111/j.1538-7836.2011.04327.x.

12. Oka T, Nishimura Y, Zang L, Hirano M, Shimada Y, Wang Z, Umemoto N, Kuroyanagi J, Nishimura N, Tanaka T. Diet-induced obesity in zebrafish shares common pathophysiological pathways with mammalian obesity. BMC Physiol. 2010; 10:21. https://doi. org/10.1186/1472-6793-10-21.

13. Ponsuksili S, Murani E, Schellander K, Schwerin M, Wimmers K. Identification of functional candidate genes for body composition by expression analyses and evidencing impact by association analysis and mapping. Biochim Biophys Acta. 2005; 1730:31-40. https://doi.org/10.1016/j. bbaexp.2005.06.004.

14. Romao JM, He ML, McAllister TA, Guan LL. Effect of age on bovine subcutaneous fat proteome: molecular 
mechanisms of physiological variations during beef cattle growth. J Anim Sci. 2014; 92:3316-27. https://doi. org/10.2527/jas.2013-7423.

15. Zahedi RG, Summers LK, Lumb P, Chik G, Crook MA. The response of serum apolipoprotein $\mathrm{H}$ to an oral fat load. Ann Clin Biochem. 2004; 41:330-4. https://doi. org/10.1258/0004563041201482.

16. Castro A, Lazaro I, Selva DM, Cespedes E, Girona J, NuriaPlana, Guardiola M, Cabre A, Simo R, Masana L. APOH is increased in the plasma and liver of type 2 diabetic patients with metabolic syndrome. Atherosclerosis. 2010; 209:201-5. https://doi.org/10.1016/j.atherosclerosis.2009.09.072.

17. Hasstedt SJ, Coon H, Xin Y, Adams TD, Hunt SC. APOH interacts with FTO to predispose to healthy thinness. Hum Genet. 2016; 135:201-7. https://doi.org/10.1007/ s00439-015-1629-3.

18. Strable MS, Ntambi JM. Genetic control of de novo lipogenesis: role in diet-induced obesity. Crit Rev Biochem Mol Biol. 2010; 45:199-214. https://doi. org/10.3109/10409231003667500.

19. Potapova IA, El-Maghrabi MR, Doronin SV, Benjamin WB. Phosphorylation of recombinant human ATP:citrate lyase by cAMP-dependent protein kinase abolishes homotropic allosteric regulation of the enzyme by citrate and increases the enzyme activity. Allosteric activation of ATP:citrate lyase by phosphorylated sugars. Biochemistry. 2000; 39:1169-79.

20. Buettner C, Muse ED, Cheng A, Chen L, Scherer T, Pocai A, Su K, Cheng B, Li X, Harvey-White J, Schwartz GJ, Kunos G, Rossetti L, et al. Leptin controls adipose tissue lipogenesis via central, STAT3-independent mechanisms. Nat Med. 2008; 14:667-75. https://doi.org/10.1038/ nm1775.

21. Brownsey RW, Boone AN, Elliott JE, Kulpa JE, Lee WM. Regulation of acetyl-CoA carboxylase. Biochem Soc Trans. 2006; 34:223-7. https://doi.org/10.1042/BST20060223.

22. Fullerton $\mathrm{MD}$, Galic S, Marcinko $\mathrm{K}$, Sikkema $\mathrm{S}$, Pulinilkunnil T, Chen ZP, O'Neill HM, Ford RJ, Palanivel R, O'Brien M, Hardie DG, Macaulay SL, Schertzer JD, et al. Single phosphorylation sites in Acc1 and Acc2 regulate lipid homeostasis and the insulin-sensitizing effects of metformin. Nat Med. 2013; 19:1649-54. https://doi. org/10.1038/nm.3372.

23. Saggerson D. Malonyl-CoA, a key signaling molecule in mammalian cells. Annu Rev Nutr. 2008; 28:253-72. https:// doi.org/10.1146/annurev.nutr.28.061807.155434.

24. Schweiger M, Schreiber R, Haemmerle G, Lass A, Fledelius C, Jacobsen P, Tornqvist H, Zechner R, Zimmermann R. Adipose triglyceride lipase and hormone-sensitive lipase are the major enzymes in adipose tissue triacylglycerol catabolism. J Biol Chem. 2006; 281:40236-41. https://doi. org/10.1074/jbc.M608048200.

25. Anthonsen MW, Ronnstrand L, Wernstedt C, Degerman E, Holm C. Identification of novel phosphorylation sites in hormone-sensitive lipase that are phosphorylated in response to isoproterenol and govern activation properties in vitro. J Biol Chem. 1998; 273:215-21.

26. Greenberg AS, Shen WJ, Muliro K, Patel S, Souza SC, Roth RA, Kraemer FB. Stimulation of lipolysis and hormonesensitive lipase via the extracellular signal-regulated kinase pathway. J Biol Chem. 2001; 276:45456-61. https://doi. org/10.1074/jbc.M104436200.

27. Buettner C, Pocai A, Muse ED, Etgen AM, Myers MG Jr, Rossetti L. Critical role of STAT3 in leptin's metabolic actions. Cell Metab. 2006; 4:49-60. https://doi. org/10.1016/j.cmet.2006.04.014.

28. Gao S, Moran TH, Lopaschuk GD, Butler AA. Hypothalamic malonyl-CoA and the control of food intake. Physiol Behav. 2013; 122:17-24. https://doi.org/10.1016/j. physbeh.2013.07.014.

29. Hu Z, Dai Y, Prentki M, Chohnan S, Lane MD. A role for hypothalamic malonyl-CoA in the control of food intake. J Biol Chem. 2005; 280:39681-3. https://doi.org/10.1074/ jbc.C500398200.

30. Gao S, Kinzig KP, Aja S, Scott KA, Keung W, Kelly S, Strynadka K, Chohnan S, Smith WW, Tamashiro KL, Ladenheim EE, Ronnett GV, Tu Y, et al. Leptin activates hypothalamic acetyl-CoA carboxylase to inhibit food intake. Proc Natl Acad Sci U S A. 2007; 104:17358-63. https://doi. org/10.1073/pnas.0708385104.

31. Chakravarthy MV, Zhu Y, Yin L, Coleman T, Pappan KL, Marshall CA, McDaniel ML, Semenkovich CF. Inactivation of hypothalamic FAS protects mice from diet-induced obesity and inflammation. J Lipid Res. 2009; 50:630-40. https://doi.org/10.1194/jlr.M800379-JLR200.

32. Mori H, Hanada R, Hanada T, Aki D, Mashima R, Nishinakamura H, Torisu T, Chien KR, Yasukawa H, Yoshimura A. Socs 3 deficiency in the brain elevates leptin sensitivity and confers resistance to diet-induced obesity. Nat Med. 2004; 10:739-43. https://doi.org/10.1038/nm1071.

33. Rahmouni K, Sigmund CD, Haynes WG, Mark AL. Hypothalamic ERK mediates the anorectic and thermogenic sympathetic effects of leptin. Diabetes. 2009; 58:536-42. https://doi.org/10.2337/db08-0822.

34. Kleinridders A, Schenten D, Konner AC, Belgardt BF, Mauer J, Okamura T, Wunderlich FT, Medzhitov R, Bruning JC. MyD88 signaling in the CNS is required for development of fatty acid-induced leptin resistance and diet-induced obesity. Cell Metab. 2009; 10:249-59. https:// doi.org/10.1016/j.cmet.2009.08.013.

35. Grove KL, Fried SK, Greenberg AS, Xiao XQ, Clegg DJ. A microarray analysis of sexual dimorphism of adipose tissues in high-fat-diet-induced obese mice. Int $\mathrm{J}$ Obes (Lond). 2010; 34:989-1000. https://doi.org/10.1038/ijo.2010.12.

36. Agar C, de Groot PG, Morgelin M, Monk SD, van Os G, Levels JH, de Laat B, Urbanus RT, Herwald H, van der Poll T, Meijers JC. beta(2)-glycoprotein I: a novel component of innate immunity. Blood. 2011; 117:6939-47. https://doi. org/10.1182/blood-2010-12-325951. 
37. Cani PD, Amar J, Iglesias MA, Poggi M, Knauf C, Bastelica D, Neyrinck AM, Fava F, Tuohy KM, Chabo C, Waget A, Delmee E, Cousin B, et al. Metabolic endotoxemia initiates obesity and insulin resistance. Diabetes. 2007; 56:1761-72. https://doi.org/10.2337/db06-1491.

38. Cani PD, Bibiloni R, Knauf C, Waget A, Neyrinck AM, Delzenne NM, Burcelin R. Changes in gut microbiota control metabolic endotoxemia-induced inflammation in high-fat diet-induced obesity and diabetes in mice. Diabetes. 2008; 57:1470-81. https://doi.org/10.2337/db07-1403.

39. Okla M, Wang W, Kang I, Pashaj A, Carr T, Chung S. Activation of Toll-like receptor 4 (TLR4) attenuates adaptive thermogenesis via endoplasmic reticulum stress. J Biol Chem. 2015; 290:26476-90. https://doi.org/10.1074/ jbc.M115.677724.
40. Rosenwald M, Perdikari A, Rulicke T, Wolfrum C. Bi-directional interconversion of brite and white adipocytes. Nat Cell Biol. 2013; 15:659-67. https://doi.org/10.1038/ ncb2740.

41. Sheng Y, Reddel SW, Herzog H, Wang YX, Brighton T, France MP, Robertson SA, Krilis SA. Impaired thrombin generation in beta 2-glycoprotein I null mice. J Biol Chem. 2001; 276:13817-21. https://doi.org/10.1074/jbc. M010990200.

42. McGrath KC, Li XH, Whitworth PT, Kasz R, Tan JT, McLennan SV, Celermajer DS, Barter PJ, Rye KA, Heather AK. High density lipoproteins improve insulin sensitivity in high-fat diet-fed mice by suppressing hepatic inflammation. J Lipid Res. 2014; 55:421-30. https://doi.org/10.1194/jlr. M043281. 